\title{
SASTRA, PENGAJARAN, DAN PENGEMBANGANNYA
}

\section{(LITERATURE, TEACHING, AND DEVELOPMENT LANGUAGE OFFICE OF RIAU ISLANDS)}

\author{
Dwi Sutana \\ Kantor Bahasa Provinsi Kepulauan Riau \\ Jalan Rumah Sakit No. 3, Tanjungpinang, Kepulauan Riau \\ Pos-el: dwi.sutana@gmail.com \\ Telepon 081316467829
}

\begin{abstract}
Literature teaching aims to act as a tool to carry forward the values of ethics and morals in life. It is also one of the means for the development of literature which aims to expand literature field as well as to increase literature appreciation, improve the quality of literature, and to excite literature enthusiasts. These can only be achieved with the implementation of literature teaching. Engaging students with literature will increase their appreciation and interests. Through this way, the teacher can enhance the teaching of literature to be better. The growing literature will open up our mind to new experiences or to invite us to organize these experiences with a new way. Moreover, this can be a tool to generate the people's opinions in the society
\end{abstract}

Key words: literature, teaching, development

\begin{abstract}
Abstrak
Tujuan pengajaran sastra sebagai alat untuk meneruskan nilai-nilai etika dan moral dalam kehidupan. Selain itu, pengajaran sastra juga merupakan salah satu sarana untuk pengembangan sastra yang bertujuan untuk meluaskan wilayah pembaca atau penikmat sastra serta menumbuhkan apresiasi, meningkatkan mutu hasil sastra, dan menggairahkan penciptaan sastra. Dengan pengajaran sastra diharapkan ketiga hal itu dapat dicapai. Dengan melibatkan siswa secara langsung dengan sastra akan menumbuhkan daya apresiasi dan peningkatan cinta siswa terhadap sastra. Dengan cara seperti itu guru dapat meningkatkan pengajarannya menjadi lebih baik, sehingga membantu dalam pengembangan sastra. Sastra yang berkembang akan membuka batin kita bagi pengalamanpengalaman baru atau mengajak kita untuk mengatur pengalaman tersebut dengan suatu cara baru dan dapat sebagai alat untuk mencetuskan pendapat-pendapat yang hidup di dalam masyarakat.
\end{abstract}

Kata kunci: sastra, pengajaran, pengembangan

\section{Pendahuluan}

"Pekikan" bahwa sastra itu terpinggirkan dan belum menjadi mata pelajaran yang "berwibawa" dalam dunia pendidikan terus saja menderu hampir setiap saat (Trisman, 2011: 207). Dengan begitu, - selanjutnya
Trisman menjelaskan - "nasib" pembelajaran sastra tidak jauh berbeda dengan ungkapan klasik yang mengatakan bahwa "bahasa dan sastra itu seperti sekeping mata uang". "Beban" berat harus dipikul oleh pembelajaran bahasa dan sastra. Pembel- 
ajaran bahasa dan sastra masih belum sepenuhnya dapat menempatkan diri pada posisi yang sebenarnya dalam kancah pendidikan yang disebabkan oleh berbagai faktor. Dari kenyataan itu, kita tidak perlu mencari “kambing hitam'. Kita menyadari bahwa dampak globalisasi menjadikan dunia ini seperti sebuah perkampungan saja. Terbukanya berbagai kemudahan dalam perlintasan dunia menyebabkan munculnya berbagai pengaruh dan tantangan dalam kehidupan bangsa di dunia ini. Tidak ada cara lain bagi bangsa kita ini harus mempersiapkan diri dalam menghadapi pengaruh dan tantangan global tersebut jika tidak ingin hanya sebagai penerima dampak dan menjadi penonton saja.

Pendidikan merupakan peranti penting dalam mempersiapkan sumber daya manusia guna menghadapi persaingan global. Semua bidang studi, termasuk bahasa dan sastra, diharapkan mampu berperan dalam menumbuhkembangkan wawasan dan kemampuan siswa agar menjadi generasi yang andal di masa mendatang.

Sebenarnya, pendidikan itu tidak hanya dilakukan di sekolah, tetapi juga di rumah. Pendidikan di rumah pelaksanaannya dapat disampaikan dengan berbagai macam cara. Ada yang disampaikan secara lisan sebagai cerita pengantar tidur, dongeng sebelum tidur, atau digunakan juga dalam bentuk dan suasana komunikasi lain.

Pendidikan dengan penyampaian secara lisan sebenarnya sudah merupakan suatu tradisi yang membudaya dalam masyarakat kita pada zaman dahulu. Banyak hikmah yang dapat dipetik dengan tradisi lisan tersebut, misalnya (1) membuat jalinan kasih sayang orang tua dan anak menjadi lebih dekat, lekat, mesra dan mengesankan; (2) membangun kecerdasan emosional, anak akan belajar nilai-nilai etika dan moral dalam kehidupan; dan (3) mengembangkan daya imaji dan pengasahan daya kreasi se- cara intensif yang berlangsung secara berkesinambungan.

Kini, tradisi itu bagai mutiara yang hilang. Di dalam keluarga jarang berlangsung suasana kekeluargaan sebagaimana yang terjadi dahulu. Apalagi, dalam pengenalan sastra dan budaya hampir tidak lagi melekat dalam tradisi keluarga. Dalam perkembangannya di zaman sekarang ini, pendidikan sastra dan budaya itu lebih banyak dilakukan di sekolah. Pendidikan di sekolah, keberlangsungannya sebenarnya kalau dihitunghitung hanya beberapa menit dari beberapa jam setiap minggunya. Di sekolah hanya sebagian kecil dari sejumlah mata pelajaran yang diajarkan. Dengan pengajaran berbagai macam ilmu, pengajaran bahasa dan cabangcabang kesenian dilakukan, selain sastra. Guna mendukung keeksistensian tersebut, tentu pengajaran sastra sangat diperlukan. Pengajaran sastra diberikan kepada anak sebagai suatu pembekalan sejak dini agar kelak menjadi insan yang beriman dan bertakwa kepada Tuhan Yang Maha Esa.

Pengajaran sastra merupakan proses belajar-mengajar yang objek kajiannya dan bahan-bahannya berupa karya sastra, ilmu sastra, dan penghadiran kehidupan sastra di lingkungan sekolah. Pengajaran ini sebagai salah satu upaya untuk mencapai kualitas hidup manusia yang ideal, sebagaimana diisyaratkan oleh tujuan pendidikan nasional.

Tujuan pengajaran sastra merupakan alat untuk meneruskan nilai-nilai etika dan moral dalam kehidupan. Selain itu, sastra juga berfungsi untuk membuka batin kita bagi pengalaman-pengalaman baru atau mengajak kita untuk mengatur pengalaman tersebut dengan suatu cara baru. Sastra dapat juga sebagai alat untuk mencetuskan pendapat-pendapat yang hidup di dalam masyarakat.

Taksonomi Bloom (dalam Hadi, 1998: 32) mengatakan bahwa tujuan pendidikan 
(yang kita realisasikan dalam pengajaran) meliputi tiga aspek, yaitu kognitif, afektif, dan psikomotorik. Tujuan psikomotorik dikaitkan dengan penguasaan keterampilan siswa, tujuan kognitif untuk pengetahuan siswa, dan afektif lebih ditekankan pada sikap siswa. Begitu pula pengajaran sastra, apresiasi bahasa dan sastra Indonesia memuat tiga aspek tujuan tersebut. Hanya saja aspek afektiflah yang lebih ditekankan di sini. Apresiasi bahasa dan sastra Indonesia selain untuk tingkat pemahaman juga bertujuan untuk menanamkan tingkat apresiasi siswa. Meskipun demikian, tidak harus ketiga aspek tujuan tersebut dipisahkan secara tegas. Hal ini disebabkan oleh ketiganya memang merupakan aspek-aspek yang tidak terpisahkan satu dengen yang lain.

Dari uraian tersebut dapat kita ketahui tujuan dan peranan pengajaran sastra bagi siswa. Secara singkat dapat dikatakan bahwa sastra merupakan alat untuk menanamkan nilai-nilai etika dan moral dalam kehidupan. Akan tetapi, peranan pengajaran sastra itu sendiri jarang dibicarakan orang. Hal inilah yang menarik dan kita perlu membahasnya.

\section{Sastra, Pengajaran, dan Pengembangannya}

Ada tiga hal yang akan dibicarakan pada uraian berikut yang akan digunakan untuk menjelaskan pengertian-pengertian sebagai dasar dalam pembahasan selanjutnya, yaitu sastra, pengajaran sastra, dan pengembangan sastra.

\subsection{Sastra}

Sampai saat ini batasan sastra belum dapat dikemukakan secara tegas. Hal ini disebabkan adanya berbagai pihak dan berbagai pendekatan yang berbeda-beda (Hadi, 1998: 33). Pada umumnya sastra yang berasal dari kata literature dalam bahasa Barat modern di- artikan sebagai segala sesuatu yang tertulis, pemakaian bahasa dalam bentuk tertulis (Teeuw, 1988: 22). Sastra dalam bahasa Indonesia berasal dari bahasa Sanskerta; asal kata sas, dalam kata kerja turunan berarti mengarahkan, mengajar, memberi petunjuk atau instruksi. Akhiran tra biasanya menunjukkan alat, sarana. Maka, satra adalah untuk mengajar, buku petunjuk, buku instruksi atau pengajaran (Teeuw, 1988: 22).

Sastra merupakan sebuah ciptaan, kreasi, bukan semata-mata sebuah imitasi. Sang seniman menciptakan sebuah dunia baru, meneruskan proses penciptaan di dalam semesta alam, bahkan menyempurnakannya (Hartono, dalam Hadi, 1998: 33). Begitu pula Rene Wellek dan Austin Warren (1989: 3) dalam bukunya Teori Kesusatraan mengatakan bahwa sastra adalah kegiatan kreatif sebuah karya seni. Sastra memuat nilai-nilai etika dan moral dalam kehidupan. Sastra merupakan cerminan masyarakat. Dengan demikian, sastra merupakan karya sosial sekaligus karya individu yang sifatnya subjektif karena bergantung pada subjektivitas si pengarang. Meskipun demikian, pengarang sedikit banyak dipengaruhi oleh lingkungan sosial budaya yang melatarbelakanginya. Dengan demikian sastra memuat nilai-nilai yang tinggi bagi hidup dan kehidupan. Sastra memberi instruksi, mengarahkan, mengajarkan sesuatu yang bernilai kepada siswa.

Mengingat nilai-nilai yang termuat di dalamnya, siswa diusahakan agar selalu dekat dan akrab dengan sastra. Usaha itu salah satunya dilakukan melalui pengajaran sastra di sekolah. Pada hakikatnya, pengajaran sastra adalah untuk menumbuhkan apresiasi siswa terhadap sastra sehingga siswa dapat menghargai dan mencintai sastra. Dengan begitu siswa dapat belajar dari sastra tersebut. 


\subsection{Pengajaran Sastra}

Pengajaran sastra sampai saat ini masih menjadi permasalahan yang pelik. Bagaimana mengajarkan sastra yang baik, yang apresiatif, masih menjadi persoalan para guru. Jeleknya lagi, hanya gurulah yang menjadi tuduhan pertama dalam masalah ini. Meskipun predikat itu tidak sepenuhnya benar, tetapi tidak dapat disalahkan jika masyarakat menjatuhkan vonis bahwa gurulah yang bertanggung jawab dengan masalah ini. Hal ini disebabkan gurulah yang berhubungan langsung dengan praktik pengajaran sastra. Akan tetapi, apakah pihak lain tidak terlibat sama sekali? Bagaimana dengan siswa sendiri, buku-buku acuan, fasilitas sekolah (perpustakaan), dan sebagainya?

Ali (1975: 6) mengungkapkan ada lima masalah dalam pengembangan sastra, yaitu (1) apresiasi sastra dalam masyarakat masih tetap dianggap terbatas, (2) penelitian sastra yang menunjang pengembangan sastra masih belum meluas, (3) penerbitan bukubuku sastra masih tetap sedikit jumlahnya, baik jumlah naskah yang dicetak maupun jumlah eksemplarnya, (4) penerbitan hasilhasil penelitian masih kurang, dan (5) pengajar dan pelajaran sastra masih perlu ditingkatkan mutunya. Dengan demikian, pihak yang sedikit banyak terlibat langsung dalam kehidupan sastra Indonesia adalah sastrawan, penerbit, editor majalah sastra, ahli sastra, pengajar sastra, kritikus, petugas-petugas pemerintah dalam bidang sastra.

Dari pernyataan tersebut dapat diketahui bahwa dalam kenyataannya pengajaran sastra yang ada memang masih banyak menghadapi masalah. Pengajaran sastra yang kurang akan mempengaruhi pengembangan sastra.

Pada hakikatnya pengajaran sastra adalah untuk mendidik apresiasi siswa terhadap sastra, tetapi kenyataannya lulusan SLTA yang ada sekarang tidak atau kurang memiliki daya apresiasi yang baik. Bahkan, bacaan sastranya sendiri tidak banyak yang diketahui siswa. Bagaimana siswa dapat memiliki apresiasi terhadap sastra jika mereka membaca sastra saja tidak pernah. Inilah yang ada dalam pengajaran sastra yang masih terdapat sampai saat ini. Guru cenderung untuk mengajarkan teori sastra misalnya, tokoh, tema, alur, tokoh-tokoh angkatan, sejarah dan semacamnya. Siswa tidak dibuat akrab dengan sastra itu sendiri, tetapi justru seolah-olah dibuat jarak.

Masalah-masalah yang ada itu sangat mungkin disebabkan oleh guru sendiri tidak atau kurang memiliki apresiasi terhadap sastra. Lebih-lebih jika guru kurang menyadari akan peranan pengajaran sastra sehingga pengajaran sastra yang ada hanya turuntemurun, seperti apa yang terjadi dalam pendidikan gurunya. Hal inilah yang menyebabkan atau memengaruhi cara guru mengajarkan sastra.

Peranan pengajaran yang tergantung bagi siswa adalah untuk menumbuhkan apresiasi siswa terhadap sastra. Jika dilihat dari peranan pengembangan sastra itu sendiri maka pengajaran sastra merupakan salah satu sarana untuk mengembangkan sastra. Meskipun sebenarnya pengajaran sastra pertama-tama bukan untuk membentuk calon-calon satrawan, dan pengajaran sastra tidak secara langsung dapat untuk menjadikan siswa cinta sebagai sastrawan, pengajaran sastra merupakan salah satu sarana untuk mengembangkan sastra. Akan tetapi, dalam masyarakat sastra, lebih-lebih guru yang mengajarkan sastra tidak boleh mengabaikan begitu saja dari masalah yang ada. Apalagi kalau kita sudah sadar akan arti pentingnya pengajaran sastra dan hakikat sastra.

Telah disinggung di depan bahwa tujuan pengembangan sastra, yakni untuk (1) memperluas pembaca atau peminat sastra dan menanamkan apresiasi sastra secara le- 
bih mendalam, (2) meningkatkan mutu hasil sastra, dan (3) menggairahkan hasil penciptaan sastra. Untuk itu, dalam pembahasan berikutnya akan dikemukakan peranan pengajaran sastra bagi pengembangan sastra dengan melihat ketiga hal yang menjadi tujuan pengembangan sastra tersebut di atas.

Hal pertama yang harus dilakukan atau jalan yang ditempuh dalam pengajaran sastra dewasa ini, yang berkaitan dengan tujuan pengembangan sastra adalah (1) penyediaan buku-buku pedoman yang sesuai dengan tujuan pengajaran sastra, (2) penyusunan buku pedoman pengajaran sastra yang baik, (3) perbaikan kurikulum dan silabus pengajaran sastra, (4) perbaikan metode pengajaran sastra dengan metode evaluasinya, (5) peningkatan penataran guru-guru sastra, dan (6) peningkatan kombinasi antara semua pihak yang berhubungan dengan pengajaran sastra (Depdikbud, 1975: 176).

Dari uraian di atas, jika pengajaran itu sudah sesuai atau paling tidak mendekati apa yang menjadi idealnya pengajaran sastra, yang kita harapkan adalah sebagai berikut.

\section{a. Meluasnya wilayah pembaca sastra}

Kalau kita lihat dewasa ini bacaan sastra hanya dibaca oleh orang-orang tertentu, bagi yang tertarik dan berminat terhadap sastra. Adapun masyarakat kebanyakan lebih suka membaca bacaan yang sifatnya umum atau populer. Hal tersebut dapat dimaklumi, di samping isi karya sastra semacam itu memang berat, apabila tidak dibiasakan untuk membaca karya-karya semacam itu. Situasi pengajaran kita belum menciptakan untuk bisa akrab dengan karya sastra, tetapi kita tidak boleh berhenti hanya karena ada permasalahan itu.

\section{b. Meningkatkan mutu hasil sastra \\ Pengajaran sastra yang baik akan dapat meningkatkan mutu hasil sastra. Hal ini da-}

pat terjadi karena buah atau hasil dari pengajaran sastra yang baik dan andal. Dari sastrawan yang andal akan lahir karya satra yang bermutu. Hal ini lebih-lebih jika dikaitkan dengan kerja sama sekolah dengan berbagai pihak yang berkaitan dengan sastra, seperti sastrawan atau penerbit. Dari pengajaran sastra yang ada tentunya guru bersama siswa membahas permasalahan yang ada dalam karya sastra, Dari yang bersifat hafalan sampai ke hal-hal yang mendalam. Tidak saja dalam pengajaran sastra, tetapi bagaimana cara meresensi buku, mengkritik, dan sebagainya. Kerja sama yang dimasudkan di atas adalah kerja sama yang lebih ditekankan pada situasi pengajaran sastra yang ada dengan pihak lain, seperti sekolah dengan penerbit. Dari permasalahan yang ada dalam pengajaran sastra di sekolah kemudian diadakan dialog dengan pihak lain, misalnya sekolah dengan penerbit atau pihak satrawannya sendiri. Di situlah pihak lain dapat digunakan untuk meningkatkan hasil sastra yang ada. Seorang sastrawan meskipun berdiri bebas dalam keyakinanya untuk mencipta, tetapi sastrawan yang baik berusaha untuk memberikan apa yang terbaik untuk penikmat sastra, lebih-lebih jika hal ini digunakan untuk bahan pengajaran sastra. Dari uraian di atas telah dikemukakan salah satu sarana, untuk pengembangan sastra ialah pengajaran dan pelajaran bahasa dan sastra Indonesia.

\section{c. Menggairahkan penciptaan sastra}

Pengajaran sastra bukan untuk membentuk siswa menjadi seorang sastrawan, melainkan tidak jarang dijumpai dengan adanya bakat dan dari pengajaran sastra yang didapat di sekolah bisa menjadikan seseorang menjadi sastrawan. Berdasarkan pengalamannya dalam bidang sastra dan ditambah dengan pengalamannya dalam pengajaran sastra (Hadi, 1998: 39). 
Pengajaran sastra yang baik bisa menumbuhkan siswa untuk lebih dekat dan lebih mencintai sastra. Seperti contoh yang dikemukakan di atas tentang adanya kegiatan sastra di sekolah dapat menumbuhkan apresiasi atau penghargaan siswa terhadap karya sastra bahkan sampai pada tahap mencintai sastra. Salah satu wujud penghargaan dan cintanya seseorang terhadap sastra adalah keinginan untuk selalu mencipta karya sastra, entah itu penulisan puisi ataupun penulisan cerpen. Suasana pengajaran yang kompetitif dalam bidang sastra memunculkan "sastrawan-sastrawan baru". Hal ini ditunjang dengan adanya majalah dinding atau majalah sekolah yang merupakan penciptaan sastra di sekolah. Demikan pula akibat dari luar sekolah, siswa yang merasa mampu untuk menulis dan mendapat bimbingan serta dorongan dari guru akan ada kemauan untuk menulis, tidak hanya untuk lingkup sekolah, bahkan sampai di luar sekolah.

Kegairahan penciptaan sastra sangat erat berkaitan dengan pembahasan sebelumnya. Sastrawan yang baik adalah sastrawan yang tanggap akan situasi di sekelilingnya. Dalam hal pencapaian ini dengan diketahuinya situasi pengajaran di sekolahsekolah, kebutuhan sastra pendidikan di sekolah-sekolah menantang para sastrawan untuk memenuhi kebutuhan tersebut. Untuk itu, digunakan sebagai spirit untuk mencipta karya sastra. Dengan demikian, ada dorongan untuk menciptakan gairah penciptaan sastra.

\section{d. Potensi Siswa SLTA dalam Pengem- bangan Sastra}

Siswa SLTA menurut ilmu psikologi dimasukkan dalam kategori masa adolesen. Masa adolesen memiliki sikap-sikap yang spesifik. Sifat-sifat yang tampak pada masa adolesen antara lain tidak mau diperlakukan sebagai anak lagi, mulai sadar akan diri- nya sendiri, pemberani, dinamis, berbicara dan berbuat serba keras, gemar mengusik dan bertengkar, ingin dikagumi, mulai melakukan sosialisasi eksploratif, dan ingin mendapatkan penghargaan (Sujanto dalam Hadi, 1998: 40).

Masih menurut Sujanto, kekuatan yang sangat ampuh mempengaruhi perkembangan psikosifik siswa SLTA, menunjukkan adanya perubahan atau perkembangan dalam hal seksualitas, fantasi, emosi, kemauan, pikiran, estetika, dan religi. Hal itu sejalan dengan apa yang diungkapkan oleh Gothe (dalam Hadi, 1998:41) berkenaan dengan mereka yang kira-kira sebaya dengan siswa SLTA "Padaku ada keberanian untuk hidup di dunia ini dan menanggung beban derita maupun bahagia yang dipikulkan dunia pada bahuku".

Berdasarkan pendapat di atas dapat dikatakan bahwa pada siswa SLTA terdapat potensi besar yang sangat luar biasa yang dapat disalurkan secara positif untuk kepentingan tertentu, misalnya pengembangan sastra. Melihat peluang positif yang menguntungkan, yaitu siswa SLTA yang dihubungkan dengan pengajaran sastra, kemungkinan akan dicapai hasil yang menggembirakan. Hal ini dapat terwujud dalam tiga upaya pengembangan sastra.

Pertama, meluaskan wilayah pembaca atau penikmat sastra dan menumbuhkan apresiasi. Hal ini sangat mungkin terwujud sebab siswa SLTA merupakan kelompok umur yang potensial untuk gemar membaca. Sesuai dengan sifat, sikap, dan faktorfaktor yang ada pada masa usia siswa SLTA apabila ada motivasi dan pembimbingan yang positif tentulah mereka itu akan berbuat semaksimal mungkin termasuk di dalamnya gemar menikmati karya sastra.

Kedua, meningkatkan mutu hasil sastra. Berdasarkan dari keberhasilan apresiasi seperti tersebut, sangat memungkinkan siswa SLTA akan memulai menghasilkan karya 
sastra. Sesuai dengan sifat-sifat usia sebaya siswa SLTA, tentulah mereka akan berusaha semaksimal mungkin untuk memenuhi keinginannya, termasuk di dalamnya berkarya sastra. Dengan demikian, akhirnya akan menjadi sastrawan yang andal. Ini berarti hasil mutu sastra dapat meningkat. Apabila tidak demikian, paling tidak para sastrawan termotifasi untuk menghasilkan karya sastra yang bermutu. Hal ini dimungkinkan karena pembacanya menuntut karya yang lebih bermutu lagi untuk mereka nikmati. Kualitas apresiator meningkat, menuntut sastrawan meningkatkan diri dan dengan demikian peningkatan kualitas karya sastra terdorong menjadi terwujud.

Ketiga, menggairahkan penciptaan sastra. Pada penjelasan kedua di atas, menekankan pada peningkatan kualitas karya sastra, sedangkan yang ketiga, menekankan pada kualitas penciptaannya atau kegairahan menciptakan karya sastra. Hal yang terjadi dari peningkatan apresiasi dan kualitas karya tentu saja memotivasi kegairahan penciptaannya. Gairah mencipta oleh satrawan dapat terwujud karena merupakan sisi lain yang menguntungkan dari hasil kerja yang telah disebut pada uraian pertama dan kedua. Sastrawan akan bergairah berkarya karena melihat potensi pembaca yang luas dan motivasi kompetisi positif untuk menghasilkan karya sastra yang bermutu dan beraneka ragam.

\subsection{Pengembangan Sastra}

Kegiatan-kegiatan dan usaha-usaha yang ditujukan untuk memelihara dan mengembangkan sastra supaya dapat memenuhi fungsi dan kedudukannya merupakan wujud pengembangan sastra. Dengan demikian, dalam pengembangan sastra perlu adanya perencanaan, pengarahan, dan ketentuan-ketentuan lain yang dapat dipakai sebagai dasar pengolahan keseluruhan ma- salah sastra. Pengembangan sastra itu bertujuan untuk (1) memperluas wilayah pembaca atau peminat sastra dan menanamkan apresiasi sastra secara lebih mendalam, (2) meningkatkan hasil mutu sastra, dan (3) menggairahkan penciptaan sastra (Ali dalam Hadi, 1998: 33). Jadi, pengembangan sastra di sini merupakan suatu bentuk kegiatan. Kegiatan untuk mengembangkan, memperluas peminat sastra, dan menanamkan apresiasi sastra lebih mendalam, meningkatkan mutu hasil sastra, dan menggairahkan penciptaan sastra.

\section{Kesimpulan}

Pengajaran sastra yang baik, yang apresiatif, memungkinkan terwujudnya pengembangan sastra Indonesia. Artinya, pengajaran sastra ikut mempunyai peranan dalam pengembangan sastra. Tujuan pengembangan sastra adalah untuk meluaskan wilayah pembaca atau penikmat sastra serta menumbuhkan apresiasi, meningkatkan mutu hasil sastra, dan menggairahkan penciptaan sastra. Dengan pengajaran sastra diharapkan ketiga hal itu dapat dicapai. Pelibatan siswa secara langsung dengan sastra akan menumbuhkan daya apresiasi dan meningkatkan cinta siswa terhadap sastra. Dengan cara seperti itu, guru dapat meningkatkan pengajarannya menjadi lebih baik sehingga membantu dalam pengembangan sastra.

\section{Daftar Pustaka}

Ali, Lukman, 1975. Bahasa dan Sastra Indonesia. Jakarta: Bumi Restu.

Departemen Pendidikan dan Kebudayaan. 1984. Seminar Pengembangan Sastra Indonesia. Jakarta: PT Rais Utama.

- - - - . 1984. Undang-Undang RI Nomor 2 Sistem Pendidikan Nasional. Surakarta: Pabelan. 
- - - - . 1993. Kurikulum Sekolah Menengah Umum Garis-Garis Besar Program Pengajaran Bahasa dan Sastra Indonesia. Jakarta: Depdikbud.

Rosidi, Ajip. 1983. Bahasa dan Sastra Indonesia. Jakarta: Bumi Restu.

- - - - . 1983. Pembinaan Minat Baca dan Sastra. Surabaya: Bina Ilmu.

Sujanto, Agus. 1981. Psikologi perkembangan. Jakarta: Aksara Baru.

Hadi, Saryono.1998. "Peranan Pengajaran Sastra di SLTA".
Teeuw. A. 1988. Sastra dan Ilmu Sastra. Jakarta: Pustaka Jaya.

Trisman, B. 2011. “Melalui Pembelajaran bahasa dan Sastra; Harapan Akan Terajut Masa Depan Bangsa". Dalam Multilingual Vol 2 Tahun X, Desember. Palu: Balai Bahasa Sulawesi tengah.

Wellek, Rene dan Austin Warren. 1989. Teori Kesusastraan. Jakarta: Gramedia. 